\title{
SZANSE ROZWOJU POLSKIEJ TURYSTYKI WYNIKAJĄCE Z POLOŻENIA NAD BAŁTYKIEM
}

\author{
LES CHANCES DU DEVELOPPEMENT DU TOURISME \\ POLONAIS RESULTANT DE LA SITUATION DU PAYS \\ AU BORD DE LA BALTIQUE
}

\author{
THE CHANCES FOR THE DEVELOPMENT OF POLISH \\ TOURISM BASED ON THE SEASIDE LOCATION
}

\begin{abstract}
Artykuł przedstawia szanse rozwoju turystyki, uwarunkowane położeniem nadbałtyckim. Skoncentrowano uwagę na wybranych makro- mezo- i mikroskalowych problemach, których rozwiązanie jest niezbędne dla dalszego rozwoju turystyki na tym terenie. Udowodniono $\mathrm{m}$. in., że procesy integracyjne (polityczno-społeczno-ekologiczne), mające miejsce w basenie Morza Baltyckiego, w zasadniczy sposób przyczyniają się do zachowania walorów przyrodniczych samego morza, jak i jego najbliższego otoczenia. Nie przyczyniają się jednak do zauważalnego wzrostu zainteresowania Skandynawów tym terenem. Glówną uwagę w opracowaniu zwrócono na rozwiązania przestrzenne, które winny doprowadzić do przekształcenia nadmiernie obciążonej nadmorskiej strefy turystycznej.
\end{abstract}

\section{WSTĘP}

Położenie nadmorskie jest aktualnie, podobnie jak w całym okresie powojennym, jednym z głównych czynników rozwoju gospodarczego Polski. Do lat dziewięćdziesiątych decydowały o tym w pierwszym rzędzie takie funkcje, jak przemysł stoczniowy, działalność portowa czy rybołówstwo. Obecnie można przyjać a priori, że właśnie gospodarka turystyczna jest jedną z najważniejszych funkcji w hierarchii ważności czynników decydujących o sytuacji ekonomicznej polskich obszarów nadmorskich. Teza ta ma swoje odniesienie przede wszystkim do kondycji gospodarczej jednostek samorządowych położonych w wąskiej nadmorskiej strefie turystycznej. 
W niniejszym opracowaniu zostaną przedstawione tylko niektóre możliwości rozwoju gospodarki turystycznej wynikające z położenia nadbałtyckiego. Uwaga zostanie więc skoncentrowana na: a) problemach polityczno-ekonomicznej integracji wokółbałtyckiej, zmierzającej $\mathrm{m}$. in. do poprawy walorów turystycznych Bałtyku i jego stref przybrzeżnych, b) dalszej jakościowej transformacji nadmorskiej strefy turystycznej, c) turystyce przyrodniczej rozwijanej na terenach jeziorno-leśnych, położonych w tzw. Zielonym Pierścieniu Bałtyku.

2. WOKÓŁBAŁTYCKA WSPÓŁPRACA POLITYCZNO-GOSPODARCZA - SZANSA DALSZEGO ROZWOJU GOSPODARKI TURYSTYCZNEJ NA POLSKICH POBRZEŻACH I POJEZIERZACH

Jednym z podstawowych tzw. „czynników otoczenia” rozwoju gospodarki turystycznej, oprócz problemów ekonomicznych, kulturowych i innych, jest sytuacja polityczna. Można przyjąć założenie, że do początku lat dziewięćdziesiątych właśnie brak politycznego konsensusu między państwami wokółbałtyckimi był hamulcem współpracy w zakresie gospodarki turystycznej.

W basenie Morza Bałtyckiego do $1991 \mathrm{r}$. istniały trzy ugrupowania państw. $Z$ jednej strony były to kraje wchodzące w skład ugrupowania militarnego NATO, jednocześnie wysoko rozwinięte gospodarczo (EWG), a także neutralne (Szwecja, Finlandia), natomiast z drugiej - państwa słabe ekonomicznie, należące do RWPG i bloku militarnego - Układu Warszawskiego. Wzajemne poczucie zagrożenia nie sprzyjało rozwojowi gospodarki turystycznej. W tamtym okresie jedynie w miarę skuteczna była współpraca pomiędzy tymi blokami (państwami) w dziedzinie ochrony walorów (turystycznych) Bałtyku, kierowana $\mathrm{m}$. in. przez Sekretariat Komisji Helsińskiej - HELCOM.

Polski region południowego Bałtyku jest częścią tzw. Europy Bałtyckiej Europejskiego Regionu Bałtyckiego. J. K o ł o d z i e j s k i (1995) w koncepcji polityki zagospodarowania przestrzennego kraju „Polska 2000 plus”, dla celów badawczych w wyżej wymienionym regionie wyróżnił Polski Region Bałtycki (PRB), którego część nadmorską nazwał regionem lub makroregionem nadmorskim (RN).

Europejski Region Bałtycki nie stanowi obszaru o spójnych powiązaniach administracyjnych, gospodarczych, kulturowych, czy też infrastrukturalnych. Jego zdelimitowanie pozwoli jednak na kreowanie wielonarodowego regionu funkcjonalnego, szczególnie w zakresie rynku pracy, handlu, powiązań komunikacyjnych itd. (K o ł o d z i e j s k i 1996).

W obecnym dziesięcioleciu nastapiło przyspieszenie działań integracyjnych w obrębie basenu Bałtyku. Wynikają one $\mathrm{m}$. in. z doktryny o dwubiegunowym rozwoju Europy. Jednym biegunem wzrostu są bowiem państwa leżące wokół 
Morza Środziemnego (szczególnie europejskie), a drugim - państwa położone nad Bałtykiem.

Wśród najważniejszych inicjatyw, które tworzyły prawno-organizacyjne podstawy integracji państw zmierzających do ochrony Baltyku, należy wymienić konferencję premierów państw nadbaltyckich w Ronneby (1990 r.) oraz konferencję przedstawicieli rządów państw bałtyckich w Karlskoronie (1992 r.). Podczas sierpniowej konferencji w Karlskoronie przedstawiono koncepcje VASAB 2010 (Vision and strategies around the Baltic Sea - Wizje i strategie wokół Bałtyku), którą ostatecznie zaakceptowano w Sztokholmie w 1996 r. w postaci dokumentu pt.: Od wizji do dzialania.

Realizacja założeń VASAB 2010 jest możliwa $\mathrm{m}$. in. dzięki uruchomieniu funduszy strukturalnych Unii Europejskiej o nazwie Baltycki Interreg IIC (T o c z y s k i 1997). Większość projektów, które będą realizowane z wyżej wymienionego funduszu w siedmiu byłych województwach północnych, zaliczanych do programu VASAB 2010, dotyczy gospodarki turystycznej, $m$. in. sieci marin baltyckich, dziedzictwa kulturowego, turystyki przyrodniczej, transeuropejskich i regionalnych ścieżek rowerowych, kształcenia i turystyki w ramach Agendy 21 (działania mające w perspektywie XXI w. zabezpieczyć przyszłościowy i długotrwały rozwój), międzynarodowych i regionalnych oddziaływań sieci komunikacyjnej TEM/TER - Via Hanzeatica itd.

Chociaż bariery polityczne w zasadzie zostały usunięte przez różnego rodzaju procesy integracyjne w basenie Morza Baltyckiego, kilkudziesięcioletnie doświadezenia ograniczonego zaufania w dalszym ciagu negatywnie skutkują na niektóre dziedziny gospodarki, a szczególnie - ruch turystyczny.

Z czterech krajów skandynawskich (Szwecja, Dania, Norwegia, Finlandia) w 1997 r. przybyło do Polski jedynie 450,9 tys. turystów, z czego aż 30\% w interesach, w celach służbowych (B a r t o s z e w i c z 1997). Badania prowadzone przez Instytut Turystyki w Warszawie wykazuja, że liczba przyjazdów $\mathrm{z}$ roku na rok maleje. Należy także podkreślić, że ponad $31 \%$ osób przyjeżdżających ze Skandynawii zatrzymuje się tylko w dwóch nadmorskich miastach, tj. Szczecinie i Gdańsku (ok. 50\% turystów przybywa do Polski promami!). Korzystając z cennych walorów kulturalnych, rezygnują z walorów wypoczynkowych polskiego wybrzeża, które jak mogłoby się wydawać - winny być atrakcyjne dla nacji mieszkających wo wiele chłodniejszym klimacie.

Działania integracyjne, polityczno-gospodarcze, nie przyczyniają się więc bezpośrednio do wzrostu zainteresowania Skandynawów walorami turystycznymi naszego kraju. Efekty tych działań integracyjnych, szczególnie w zakresie ekologicznym, są jednak ogromne. Zachowanie walorów turystycznych Bałtyku i jego wybrzeży, jest korzyścią o wiele wyższą niżby to wynikało ze zwiększającego się strumienia ruchu turystycznego z państw skandynawskich. Między innymi dzięki funduszom pomocowym (ekokonwersja, PHARE itd.), większość wybrzeży polskich nadaje się do celów rekreacyjnych, kąielowych. 
Każdy z utworzonych euroregionów nad Bałtykiem (Pomerania, Baltic), czy też tworzonych (np. Niemen), ma przede wszystkim na celu rozwój gospodarki turystycznej. Dla przykładu celem istnienia od $1998 \mathrm{r}$. największego euroregionu w Europie - Euroregion Baltic, obejmujący pd.-wsch. Szwecję, wyspę Bornholm (Dania), byłe województwa: słupskie, gdańskie, elbląskie i olsztyńskie, Obwód Kaliningradzki (Rosja), Okręg Kłajpedy (Litwa) i Liepaja (Lotwa), jest współpraca w zakresie turystyki, ekologii itd. (rys. 1).

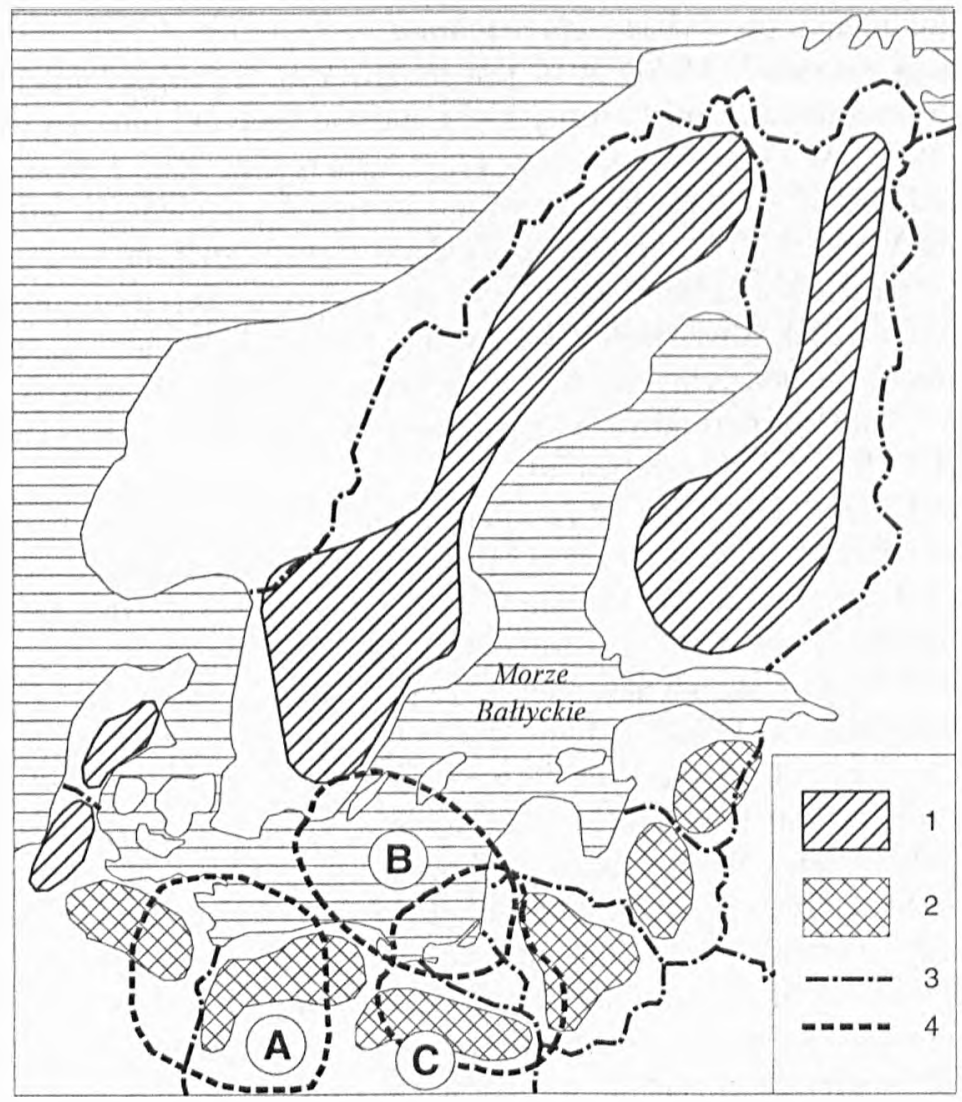

Rys. 1. Zielony Perścień Baltyku (wg autora)

1 - Zielony Pierścień Baltyku - część pólnocna, 2-Zielony Pierścień Baltyku - część południowa, 3 - Baltyk, 4-granice państw; A - Euroregion Pomerania, B - Euroregion Baltic, C - Euroregion Niemen (projektowany)

Dessin 1. L'Anneau Vert de la Baltique

1 - L'Anneau Vert de la Baltique - partie nord, 2-L'Anneau Vert de la Baltique - partie sud, 3 - La Baltique, 4 - Les frontières des états; A - L’Eurorégion Pomérania, B - L'Eurorégion Baltique, C - L’Eurorégion Niemen (projetée) 
Procesy integracyjne zachodzące w obrębie obszaru nadmorskiego zmierzaja do sukcesywnego formułowania się Europejskiego Regionu Baltyckiego, w strukturze którego jednym z głównych ogniw jest Polski Region Bałtycki z wyraźnie dominującą funkcją turystyczną.

\section{ZIELONY PIERŚCIEŃ BALTYKU (EUROPY) - INTEGRUIACY GOSPODARKĘ TURYSTYCZNĄ NA NADBAŁTYCKICH OBSZARACH JEZIORNO-LEŚNYCH}

Wyrazem działań społeczno-polityczno-ekologicznych, zmierzających do konsolidacji Europy Bałtyckiej, może być także idea Zielonego Pierścienia Bałtyku (Europy). Dla rozwoju turystyki największe znaczenie ma sam Bałtyk. Nie można jednak w koncepcjach integracyjnych pomijać drugiej przestrzeni turystycznej, jaką jest pas pojezierny biegnący paralelnie wzdłuż południowych i wschodnich brzegów morza (rys. 1). Do najważniejszych czynników, które winny być analizowane przy wyróżnieniu nowej jakości funkcjonalno-przestrzennej wokół Bałtyku, można zaliczyć:

- istnienie charakterystycznej przestrzeni powstałej podczas zlodowacenia bałtyckiego, która pod względem atrakcyjności jest trzecim obszarem turystycznym Europy (po wybrzeżach i górach); ma ona wybitne znaczenie zarówno dla turystyki poszczególnych państw, jak i całego kontynentu;

- wysoka koncentracja walorów turystycznych, w tym jednoczesność występowania jezior, lasów i urozmaiconej rzeźby, a przede wszystkim niespotykana w Europie czystość środowiska (głównie powietrza; w mniejszym stopniu - wody i szaty roślinnej) sprawia, że można stworzyć przestrzeń ekologicznie pozwalającą na utrzymanie równowagi w zdegradowanej europejskiej przyrodzie oraz wypromować turystykę zieloną (ekologiczną, alternatywną $\mathrm{i}$ inne) nastawioną na bliski kontakt człowieka z przyrodą;

- brak odzwierciedlenia wysokiej atrakcyjności przyrodniczej w sposobie zagospodarowania tego obszaru, szczególnie turystycznego;

- badany obszar a priori można uznać za najbardziej zaniedbany pod względem turystycznym w Europie;

- na całej przestrzeni od Meklemburgii po Estonię, przez minione 50 lat dominowało silnie dofinansowywane wielkoobszarowe rolnictwo państwowo-spółdzielcze; przestało ono prosperować w chwili upadku socjalistycznych form gospodarowania w byłej NRD, Polsce i Związku Radzieckim; tej ewidentnej luki gospodarczej nie potrafią wypełnić samodzielnie nowo powstałe państwa: Litwa, Łotwa, Estonia, Polska, a także częściowo Niemcy.

Wybitne wartości przyrodnicze badanego obszaru, jak również niedoskonałości w ich wykorzystywaniu zmuszają do stworzenia odpowiednich systemów ekonomicznych, prawnych oraz organizacyjnych pozwalających na wypełnienie 
określonej przestrzeni Europy konkretną wspólną aktywnością integrującą. Zielony Pierścień Bałtyku winien stać się eksperymentalnym międzynarodowym obszarem wdrażania polityki ekorozwoju.

Wprowadzanie w życie idei Zielonego Pierścienia Bałtyku może mieć bardzo duży wpływ na rozwój gospodarki turystycznej na obszarach nadbałtyckich. Pozwoli ona bowiem na: a) powrócenie do racjonalniejszego wykorzystania wybitnych elementów środowiska przyrodniczego, a szczególnie walorów turystycznych, które obecnie w wielu przypadkach są zagospodarowywane niezgodnie $\mathrm{z}$ ich wartościami; b) zwiększenie kondycji ekonomicznej zamieszkałych tam społeczności lokalnych oraz c) uczuciowo-sentymentalne związanie mieszkańców z terenami na których żyją (obecnie obszar ten charakteryzuje się jedną z najniższych gęstości zaludnienia w Europie, a także - nadal dużym odpływem ludności).

Idea Zielonego Pierścienia Bałtyku jest sukcesywnie wdrażana w życie, szczególnie w odniesieniu do gospodarki turystycznej. Między innymi w 1998 r. rząd polski podpisał tzw. Deklarację Berlińską w sprawie różnorodności biologicznej turystyki, zakładającej rozwój turystyki na obszarach wartościowych przyrodniczo (T o c z y s k i 1998). Zostały jednocześnie wyznaczone strefy przyrodniczo-turystyczne, które staną się siecią składową Europejskiego Systemu Stref Przyrodniczo-Turystycznych. W Polsce wyznaczono Północną Strefę Przyrodniczo-Turystyczna, obejmującą Pojezierze Zachodniopomorskie i Mazurskie oraz Południową Strefę - w skład której wchodzą Sudety i Karpaty. Północna Strefa w zasadzie pokrywa się z zasięgiem polskiego segmentu Zielonego Pierścienia Bałtyku.

Do najważniejszych przedsięwzięć wprowadzanych w życie na analizowanym terenie można zaliczyć: a) tworzenie sieci marin, dostępnych w odległości dnia żeglugi; b) szlaki rowerowe nawiązujące do systemów europejskich; c) sieć szlaków kajakowych; d) systemy programów poznawczych (krajobrazów, ptaków, rezerwatów dendrologicznych, wydm, skansenów, miejsc kultu religijnego) oraz e) objazdowe wycieczki studyjne, zwłaszcza szlakami: piastowskim, kopernikowskim, cystersów, teutońskim, zamków krzyżackich, zespołów klasztornych itd. (T o c z y s k i 1998).

Wyznaczony transeuropejski układ tras rowerowych EUROVELO $(\mathrm{m}$. in. przez Europejską Federację Cyklistów z siedzibą w Kopenhadze) obejmuje także Polskę nadbaltycka. Spośród 12 tras europejskich cztery włączają nasz kraj do tego układu, tj. trasa nr 5 - „Północ-Południe”; nr 8 - „Trasa stolic”; nr 10 „Trasa hanzeatycka” oraz trasa nr 12 - „Bałtyk-Adriatyk”. Dla przykładu hanzeatycki trakt rowerowy biegnie przez najbardziej atrakcyjną część Polski północnej, od niemieckiej miejscowości Ahlbeck do przejścia granicznego w Ogrodnikach. Velo Hanzeatica łączy także liczne szlaki lokalne, m. in. tworzone na nieczynnych torowiskach kolejowych, których na tym terenie jest coraz więcej. 
Według W. T o c zy s k i e g o (1998) turystyka przyrodnicza jest jedną z najważniejszych płaszczyzn zwiększenia spójności przestrzennej Obszaru Bałtyckiego. Jest także przeciwwagą dla turystyki masowej - charakterystycznej dla nadmorskiej strefy turystycznej, szczególnie w zasięgu południowych wybrzeży baltyckich.

\section{ZAGOSPODAROWANIE TURYSTYCZNE W MAKROREGIONIE PÓLNOCNYM (NADMORSKIM)}

$\mathrm{Na}$ byłe województwa sąsiadujące $\mathrm{z}$ Bałtykiem, tj. szczecińskie, koszalińskie, słupskie, gdańskie i elbląskie, przypada dokładnie jedna trzecia miejsc polskiej bazy noclegowej, wynoszącej w 1997 r. ok. 758 tys. miejsc (Turystyka... 1998). Wykorzystanie tej bazy nie jest jednak wysokie. Spośród prawie $15 \mathrm{mln}$ osób korzystających z polskiej bazy noclegowej, na strefę nadmorską przypada zaledwie 16,4\% ogółu korzystających (tab. I). Wynika to przede wszystkim $\mathrm{z}$, ,jednosezonowości", a także krótkiego okresu eksploatacji bazy.

Do wyżej przedstawionych przez Główny Urząd Statystyczny danych należy podchodzić z dużą ostrożnością. K. Kleme nt ow ski i Z. Werner (1996) uważają że poza ewidencją GUS szacunkowo znajduje się co najmniej $20 \%$ krajowych zasobów bazy noclegowej. Autor uważa, że w odniesieniu do strefy nadmorskiej, gdzie prowadził badania, różnice te są znacznie większe. Dla przykładu, wg obliczeń autora baza noclegowa w byłym woj. koszalińskim wynosiła w 1997 r. ok. 100 tys. miejsc noclegowych, gdy tymczasem wg GUS około 59 tys. Podobne różnice obserwowane są także w innych latach dziewięćdziesiątych (S z w i c h t e n b e r g 1995).

Należy podkreślić, że w 1990 r. baza noclegowa zlokalizowana tylko w gminach nadmorskich wynosiła 327 tys. miejsc noclegowych (S z w i c h t e n b e rg 1991). Absolutnie nie można zgodzić się z podawanymi przez GUS danymi, wg których w obrębie byłych województw nadmorskich (a więc łącznie - tereny nadmorskie z pojezierzami i centrami krajoznawczymi!) wynosi zaledwie 250 tys. miejsc noclegowych (Turystyka... 1998).

Niezależnie od wyżej podanych rozbieżności w danych statystycznych dotyczących bazy noclegowej i ruchu turystycznego, można przyjąć dwa wnioski ogólne, a mianowicie: a) baza ta charakteryzuje się niską efektywnością wykorzystania, oraz b) jest ona jakościowo niedostosowana do współczesnych potrzeb turystyki na świecie. Z potężnej bazy noclegowej w strefie nadmorskiej, stanowiącej 33\% ogólnej bazy w Polsce, korzysta zaledwie 16,4\% wszystkich korzystających z tej bazy w Polsce (tab. I).

Równie niekorzystna jest struktura jakościowa bazy noclegowej na obszarach nadmorskich. Na tym obszarze znikomą rolę odgrywają bowiem hotele, 
Tabela I

Rejestrowany ruch turystyczny w województwach nadmorskich w okresie październik 1995 - wrzesień 1996 Le mouvement touristiques dans les voïvodies maritimes enregistré entre le mois d'octobre 1995 et le mois de septembre 1996

\begin{tabular}{|c|c|c|c|c|c|}
\hline \multirow[b]{2}{*}{ Wyszczególnienie } & \multicolumn{3}{|c|}{ Korzystający (w tys. osób) } & \multirow{2}{*}{$\begin{array}{c}\text { Liczba wynajętych } \\
\text { pokoi w hotelach, mote- } \\
\text { lach i pensjonatach (w tys.) }\end{array}$} & \multirow{2}{*}{$\begin{array}{l}\text { Liczba udzielonych } \\
\text { noclegów w tzw. pozosta- } \\
\text { łych obiektach (w tys.) }\end{array}$} \\
\hline & ogólem & $\begin{array}{l}\text { w hotelach, mote- } \\
\text { lach i pensjonatach }\end{array}$ & $\begin{array}{c}\text { w tzw. pozostałych } \\
\text { obiektach }\end{array}$ & & \\
\hline Elbląskie & 226,8 & 94,4 & 132,4 & 76,3 & 1076,2 \\
\hline Gdańskie & 700,6 & 300,3 & 400,2 & 397,8 & 2622,1 \\
\hline Koszalińskie & 450,2 & 130,4 & 319,8 & 136,3 & 3718,8 \\
\hline Stupskie & 238,1 & 68,3 & 169,9 & 80,2 & 1809,9 \\
\hline Szczecińskie & 843,8 & 368,1 & 475,8 & 387,2 & 4370,4 \\
\hline $\begin{array}{l}\text { Województwa } \\
\text { nadmorskie }\end{array}$ & 2459,5 & 961,1 & 1498,1 & 1077,8 & 13597,4 \\
\hline Polska-ogółem & 14990,9 & 7451,2 & 7539,7 & 7978,1 & 38030,5 \\
\hline $\begin{array}{l}\text { Województwa nad- } \\
\text { morskie względem } \\
\text { Polski (w \%) }\end{array}$ & 16,4 & 12,9 & 19,9 & 13,5 & 35,8 \\
\hline
\end{tabular}

Źródło: K l e m e n towski K., 1997. 
motele i pensjonaty, które przyjmują zaledwie $12,9 \%$ ogółu korzystających z tego typu bazy noclegowej w Polsce (tab. I). Należy tu podkreślić, że jest to podstawowy typ bazy noclegowej w państwach, w których rozwinęła się turystyka na bazie 3 razy „S". Dla przykładu w Portugalii i we Włoszech baza ta stanowi $25 \%$ ogólnej bazy noclegowej kraju, natomiast w Hiszpanii i Grecji - aż $50 \%$. Proces transformacji bazy noclegowej z tzw. ,pozostałych obiektów” na hotele, motele i pensjonaty w strefie nadmorskiej jest dość powolny ( $\mathrm{S} \mathrm{z} \mathrm{w} \mathrm{i} \mathrm{c} \mathrm{h} \mathrm{-}$ te n berg 1995).

Baza noclegowa zlokalizowana na obszarach nadmorskich, chociaż odgrywa wielką rolę w statystyce turystycznej kraju, nadal nie jest tym elementem, który przyczynia się do wzrostu rangi gospodarki turystycznej Polski w basenie Morza Bałtyckiego. Sytuacja powyższa może ulec określonym pozytywnym zmianom w wyniku przyspieszenia procesu prywatyzacji bazy noclegowej. Koncepcję prywatyzacyjną majątku turystycznego zlokalizowanego w strefie nadmorskiej autor przedstawił w 1994 r. (S z w i c h t e n b e r g 1994). Mimo uzyskania pozytywnych opinii, nie została uwzględniona w pracach restrukturyzacyjnych majątku turystycznego w Polsce (S z w i c h t e n b e r g 1996).

\section{POTRZEBA PRZEKSZTAŁCENIA NADMIERNIE OBCIAZŻONEJ NADMORSKIEJ STREFY TURYSTYCZNEJ}

Można przyjąć tezę, że jednym z głównych czynników nie pozwalających na znaczny rozwój funkcji turystycznej w strefie nadmorskiej jest niewłaściwe jej zagospodarowanie przestrzenne. Obecne działania planistyczne winny skoncentrować się z jednej strony na niwelowania narosłych nieprawidłowości, zaś z drugiej - konsekwentnym wprowadzaniu nowych elementów zagospodarowania. Muszą one doprowadzić do wypełnienia nadmiernie zantropogenizowanych przestrzeni nadwodnych elementami przyrodniczymi, a także do wprowadzenia elementów sztucznych, rekompensujących niedoskonałości walorów naturalnych.

Dostosowanie form turystyki do właściwych walorów turystycznych jest jednym z ważniejszych problemów z zakresu gospodarki przestrzennej w strefie nadmorskiej. Można przyjąć założenie, że brak na polskim wybrzeżu tego dostosowania. Ma to przede wszystkim związek $\mathrm{z}$ nadmierną koncentracją zabudowy (S z w i c h t e n berg 1991).

Pierwszy typ koncentracji na polskim wybrzeżu jest w zasadzie zgodny z wymogami ekorozwoju polskiego wybrzeża, a także w miarę dostosowany do wymogów wypoczynku ( $\mathrm{S} \mathrm{z} \mathrm{w} \mathrm{i} \mathrm{c} \mathrm{h} \mathrm{t} \mathrm{e} \mathrm{n} \mathrm{b} \mathrm{e} \mathrm{r} \mathrm{g} \mathrm{1991).} \mathrm{Istnieją} \mathrm{m.} \mathrm{in.} \mathrm{w} \mathrm{miarę}$ korzystne proporcje między terenami zainwestowanymi a przestrzeniami je izo- 
lującymi. Dla przykładu, średnia odległość między nadmorskimi miejscowościami wynosi aż $3,8 \mathrm{~km}$.

Zupełnie inaczej sytuacja wygląda w odniesieniu do „koncentracji równoleżnikowej”. Wyraża się ona zarówno przez: nadmierną koncentrację zabudowy w bliskim sąsiedztwie linii brzegowej, jak również w niewłaściwym typie zagospodarowania poszczególnych pasów przyrodniczo-funkcjonalnych, ciągnących się równolegle do brzegu morskiego. Liczne przyczyny zadecydowały nie tylko o zaanektowaniu przez przedsiębiorstwa Polski centralnej i południowej najatrakcyjniejszych odcinków wybrzeży pod budownictwo wczasowe, ale także o maksymalnym zbliżeniu tych inwestycji do linii brzegowej.

Zdaniem autora jest to największe, po częściowym zdewaloryzowaniu wybrzeży w wyniku braku infrastruktury technicznej, sprzeniewierzenie się funkcji turystycznej wobec cennego środowiska przyrodniczego, stanowiącego podstawę jej rozwoju. Realizowane obecnie, w dość szybkim tempie, inwestycje komunalne sukcesywnie niwelują skutki dotychczasowego braku sieci wodno-kanalizacyjnej i oczyszczalni. Natomiast zła lokalizacja majątku noclegowo-gastronomicznego w pasie nadmorskim praktycznie uniemożliwia proces renaturyzacji tych terenów, które winny być wyłączone z jakiejkolwiek zabudowy kubaturowej.

Teza powyższa kłóci się ze znanymi w Europie modelami zagospodarowania wybrzeży. W Niemczech, Belgii, Holandii, Wielkiej Brytanii wykształciła się wyraźna pierwsza linia zabudowy (seafront, front de mer) składająca się z obiektów o bardzo dużym zagęszczeniu i wysokim standardzie. Jeżeli w przypadku zachodnioeuropejskich wybrzeży zajęcie pod budownictwo terenów przy linii brzegowej było dopuszczalne, w polskich warunkach - nie powinno ono mieć miejsca.

Projektanci zurbanizowanych pasm turystycznych doszli do wniosku, że warunki bioklimatyczne wybrzeży położonych nad chłodnymi wodami (Bałtyk, Morze Północne, kanał La Manche) nie będą sprzyjały bezpośredniemu korzystaniu z walorów przyrodniczych. Stąd też zaraz za plażą, na wydmie, zlokalizowali albo hotele, albo też wzdłuż brzegu promenadę (autostradę). Przyrodniczą ułomność wybrzeża zastąpiono z jednej strony basenami kapielowymi otoczonymi sztucznymi plażami, zaś z drugiej - obiektami rozrywkowo-handlowo-usługowymi.

Zupełnie inaczej wygląda sytuacja na wybrzeżach środkowoeuropejskich. Budownictwo, głównie „sypialno-stołówkowe”, zajęło bezpośrednie zaplecze plaży, tj. wydmę pokrytą nadmorskim borem sosnowym (rys. 2). Brakuje innych obiektów i urządzeń turystyczno-rozrywkowych. W efekcie turyści zostali „ubezwłasnowolnieni” zarówno przez projektantów, jak również przez walory przyrodnicze o względnie niskiej atrakcyjności.

W miejscowościach nadmorskich koniecznie należy przeprowadzić modernizację ich zagospodarowania przestrzennego. Winna ona polegać przede 
wszystkim na odciążeniu stref przybrzeżnych, $\mathrm{z}$ jednoczesnym przesunięciem funkcji mieszkaniowo-usługowych na południe od obecnej zabudowy wczasowo-rekreacyjnej.
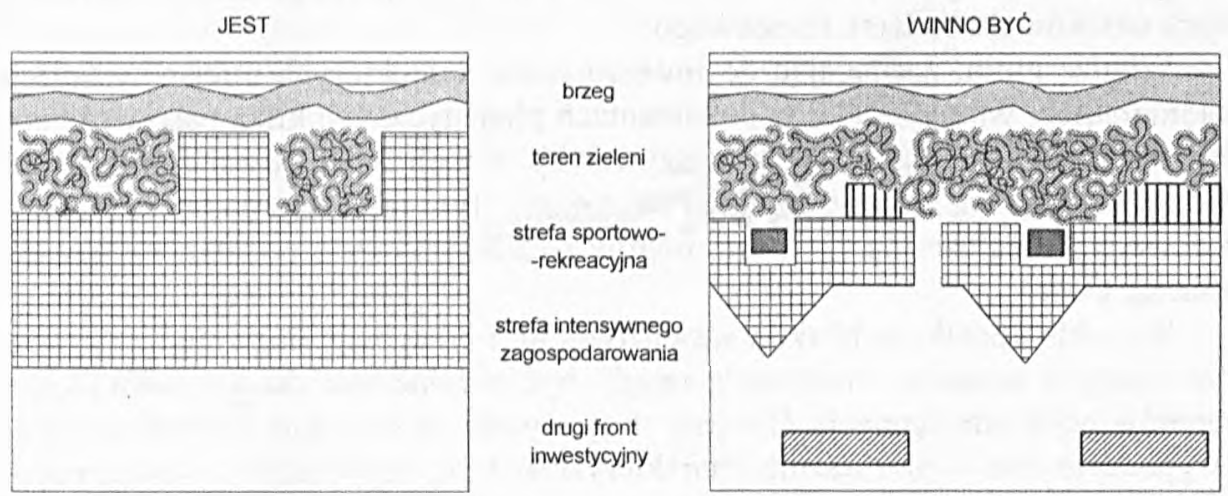

Rys. 2. Schemat zagospodarowania nadmorskiej jednostki osadniczej (wg autora)

Dessin 1. Le schéma de l'aménagement d'une unité maritime de colonisation (selon l'auteur)

Czynnikami z pogranicza planowania przestrzennego i rynku, pozwalającymi na rozwój turystyki zgodnie $\mathrm{z}$ wymaganiami walorów turystycznych, wg autora może być strefowanie podatkowe i tworzenie tzw. strategicznego areału gminnego.

Obowiązujące do niedawna przepisy o ochronie gruntów rolnych i leśnych w sposób jednoznaczny przyczyniły się do nadmiernego skoncentrowania inwestycji w pasie przymorskim. Obecne przepisy (Ustawa o ochronie... 1995), a także możliwości gmin pozwalające na różnicowanie podatków od nieruchomości, mogą wpłynąć korzystnie zarówno na strukturę przestrzenną jednostek osadniczych, jak i na procesy doprowadzające do ich odnowienia ekonomicznego. Glebowe ograniczenia nie pozwoliły $\mathrm{m}$. in. na rozwiązanie problemów komunikacyjnych zarówno w samych miejscowościach, jak również między nimi. Można postawić tezę, że przyczyniły się również do określonego regresu ekonomicznego.

W związku z powyższym proponuje się w rozwoju miejscowości nadmorskich przyjać następujące działania: a) opracować korektę istniejących planów umożliwiającą rozwój osad nadmorskich w kierunku południowym; b) przeprowadzić strefowanie, które umownie tutaj nazwano ,podatkowym”, oraz c) wygospodarować tzw. strategiczny areał gminny.

Zoning podatkowy winien różnicować nie tylko podatki, ale także przepisy budowlane w poszczególnych pasach wzdłużbrzeżnych. J. Blakley (G o r z e - 
1 a k 1991) podaje, że przepisy budowlane mogą być wykorzystane w sposób bardziej elastyczny w celu przyciagnnięcia kapitału i uzyskania pewnych korzyści dla społeczności lokalnej. Zawieszenie dla konkretnego inwestora niektórych sztywnych przepisów (np. ustaleń planu przestrzennego) o wykorzystaniu terenu, gęstości zabudowy, może być obwarowane wymogiem przeznaczenia pewnych środków do budżetu terenowego.

Władze gmin, zachęcając do inwestowania w niektórych miejscowościach nadmorskich, winny ustalić w dokumentach planistycznych kilka pasów równoległych do linii brzegowej. Obowiazzywałyby w nich zróżnicowane podatki od nieruchomości wg zasady: im dalej od morza - tym mniejszy podatek. Pas położony $\mathrm{w}$ odległości np. $2-5 \mathrm{~km}$ mógłby być zwolniony z podatku na pewien znaczący okres.

Wysokie podatki w bliskim sąsiedztwie linii brzegowej pozwolą na uzyskanie cennych terenów, które będą mogły być przyłączone do już istniejących terenów ogólnodostępnych. Obecnie w tym pasie są liczne obiekty wczasowo-wypoczynkowe - przeważnie charakteryzujące się najwyższymi wskaźnikami użytkowania terenu. Podatki winny być tak dotkliwe, aby skłoniły właścicieli obiektów do rezygnacji z części zajmowanego terenu.

Powyższy zoning pozwoli na: a) deglomerację miejscowości nadmorskich, b) budowę obwodnic, oraz c) lokalizację drugich domów w tzw. ,zapleczu miejscowości" (rys. 3).

Zastosowane instrumenty finansowe i planistyczne w znacznym stopniu pozwolą na uporządkowanie pierwszych, odmorskich stref i na pełniejszą aktywizację gospodarczą wybrzeża. Wprowadzenie nowych form zainwestowania w południowej części poszczególnych miejscowości może stać się źródłem odnowy tych jednostek osadniczych, obecnie często będących w stadium stagnacji bądź w początkowej fazie upadku.

Szczególnie istotne znaczenie będzie miał kształtujący się tzw. „drugi front inwestycyjny". Z jednej strony będzie on obejmował nowe zainwestowanie, organicznie związane $\mathrm{z}$ istniejącymi miejscowościami nadmorskimi (w następstwie deglomeracji stref przybrzeżnych!), a z drugiej - enklawy budownictwa turystycznego, przede wszystkim „drugich domów”. Prowadzone przez autora badania na terenie Pobrzeża Słowińskiego wykazały, że w odległości $2-5 \mathrm{~km}$ od linii brzegowej są liczne tereny z odpowiednimi warunkami do lokalizacji tego typu budownictwa (rys. 3).

$\mathrm{Z}$ problemem zoningu podatkowego bardzo ściśle wiąże się zagadnienie tzw. „strategicznego areału gminnego”. Czynnikiem uniemożliwiającym realizację wielu inwestycji ogólnoosiedlowych (gminnych), jak np. obwodnic, urządzeń komunalnych, centrów handlowo-usługowo-rekreacyjnych itd. jest brak odpowiednich terenów dla tego typu inwestycji. W związku z powyższym gminy winny podjąć starania zmierzające do tworzenia wspomnianego strategicznego areału. 


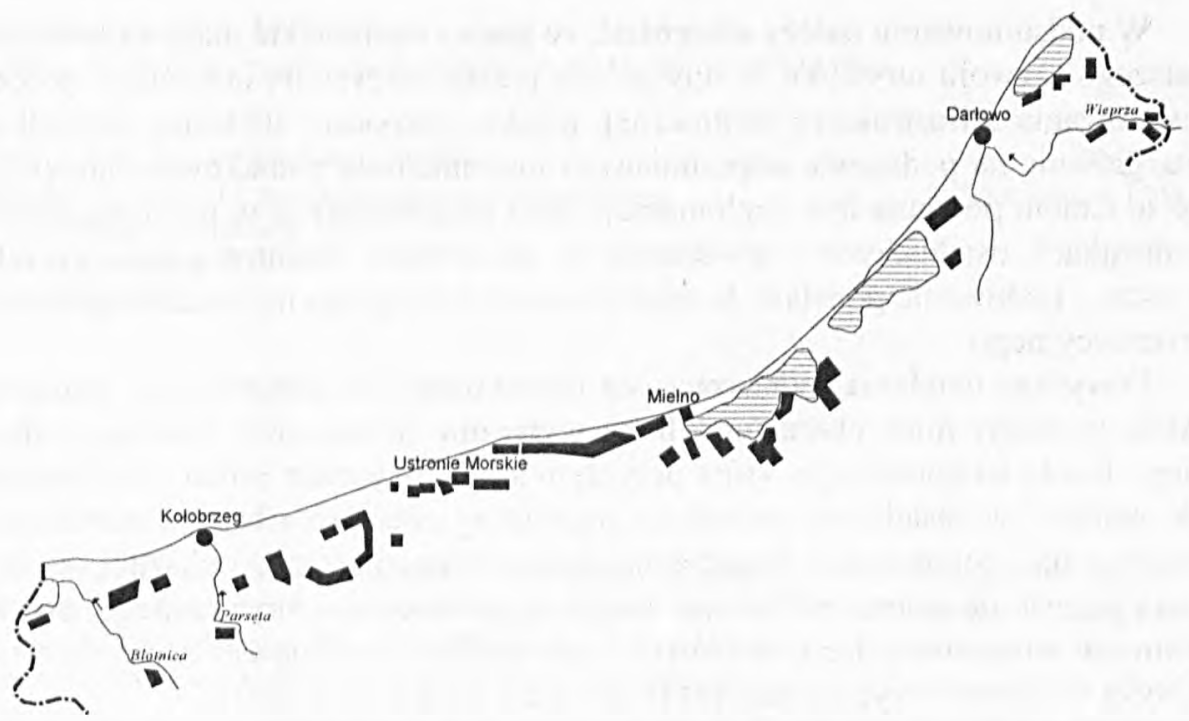

Rys. 3. Obszary potencjalnej lokalizacji „drugich domów” w strefie nadmorskiej (wg autora)

Dessin 3. Les terrains de la localisation des ,résidences secondaires” dans la zone maritime

Z funduszy gminnych należy kupować poszczególne działki, łączyć je - tworząc tereny niezbędne dla realizacji większych przedsięwzięć.

Dwa czynniki sprzyjają tworzeniu tego areału gminnego (osiedlowego), a mianowicie: organizacyjny i finansowy. Po 1999 r. wszystkie gminy będą opracowywały plany zagospodarowania przestrzennego. Zaistnieje więc możliwość skonkretyzowania ważnych dla miejscowości inwestycji, jak również odpowiednich terenów pod te inwestycje.

Istotniejszym elementem od wyżej wymienionych, sprzyjającym porządkowaniu miejscowości, są jednak nowe możliwości finansowe gmin. Większość gmin nadmorskich należy do grupy najbogatszych jednostek samorządowych w Polsce (S z w i c h t e n b e r g 1995). Gminy te są w zasadzie w końcowym etapie pełnej organizacji podstawowej infrastruktury technicznej, przede wszystkim wodociagowej, kanalizacyjnej, utylizacyjnej, energetycznej, gazowej i telefonicznej. W związku z powyższym wiele gmin nadmorskich przechodzi do kolejnego etapu rozwojowego charakterystycznego dla okresu transformacyjnego, a mianowicie - porządkowania terenów ogólnodostępnych i tworzenia nowych walorów turystycznych typu: baseny, korty, pola golfowe, czy nawet rezerwaty przyrody, parki, osłony leśne.

Rezerwowanie odpowiednich terenów pod większe przedsięwzięcia osiedlowe (gminne) pozwoli na osiagnięcie maksymalnych korzyści przez gminę, a tym samym - całą społeczność lokalna. 
W podsumowaniu należy stwierdzić, że gminy nadmorskie mają duże szanse dalszego rozwoju turystyki. Winny jednak przede wszystkim dokończyć proces instalowania infrastruktury technicznej, a także rozpocząc działania porządkowe, głównie na podstawie wspomnianych instrumentów podatkowo-planistycznych. Celem powinna być deglomeracja stref przybrzeżnych w poszczególnych jednostkach osadniczych i utworzenie w ich obrębie terenów rekreacyjnych, a także - budowanie podstaw do funkcjonowania drugiego nadmorskiego frontu inwestycyjnego.

Powyższe działania, odnoszące się do istniejących miejscowości nadmorskich, powinny mieć charakter tylko i wyłącznie jakościowy. Realizacja drugiego frontu nadmorskiego, która przyczyni się do pewnych zmian ilościowych, nie wpłynie w zasadniczy sposób na nadmierne obciążenie brzegu morskiego. Badania nad pojemnością turystyczną analizowanego terenu, wskazuja, że istnieją jeszcze określone możliwości zwiększenia obciążenia turystycznego, szczególnie w miejscowościach, w których ruch weekendowy nie kumuluje się z turystyką wczasowo-wypoczynkową (S z w i c h t e n b e r g 1991).

\section{PIŚMIENNICTWO}

B a r $t$ o s z e w i c z W., 1997, Cele i motywy przyjazdów do Polski, Inst. Turystyki, Warszawa. G or z e 1 a k G., 1991, Omówienie ksiqżki E. J. Blakely'a „Planowanie gospodarczego rozwoju lokalnego", [w:] Gmina. Przedsiębiorczość. Promocja. Studia regionalne i lokalne, 7(40).

K I e m e n t o w s k i K., 1997, Rejestrowany ruch turystyczny w Polsce w 1996 r., „Problemy Turystyki", nr 1-4.

K l e m e n t o w s k i K., W e r n e r Z., 1996, Ocena wiarygodności danych statystycznych GUS dotyczqcych zasobów bazy noclegowej, Inst. Turystyki, Wrocław.

Koncepcja polityki przestrzennej zagospodarowania kraju „Polska 2000 plus”. Wstęna koncepcja, 1995, Centralny Urząd Planowania, J. Kołodziejski (red.), Warszawa.

K o ł o d z i e j s k i J., 1996, Uwarunkowania ekorozwoju w regionie „Baltyk-Pomorze”, [w:] Ekologiczne uwarunkowania rozwoju turystyki w makroregionie Baltyk-Pomorze. Szanse i zagrożenia, A. Szwichtenberg (red.), Wojewoda Koszaliński oraz PTE, Koszalin.

$\mathrm{S} \mathrm{z}$ w i c h t e n b e rg A., 1991, Stymulatory i bariery rozwoju funkcji turystycznej w polskiej strefie nadbattyckiej, Koszaliński Ośrodek Naukowo-Badawczy, Koszalin.

S z w i c h t e n b e r g A., 1994, Prywatyzacja majqtku turystycznego w województwie koszalinskim, „Rynek Turystyczny”, nr 6(20), nr 7(21).

S z w i c h t e n b e r g A., 1995, Gospodarka turystyczna w okresie przejściowym, Politechnika Koszalińska, Koszalin.

S z w i c h t e n b e r g A., 1996, Propozycje legislacyjne usprawniajqce gospodarkę turystycznq $w$ Polsce, [w:] Ekologiczne uwarunkowania rozwoju turystyki w makroregionie Baltyk-Pomorze. Szanse i zagrożenia, A. Szwichtenberg (red.), Wojewoda Koszaliński, PTE, Koszalin.

T o c z y s k i W., 1997, Nowe rozdanie w integracji baltyckiej, „Czas Morza”, nr 2(9).

T o c z y s k i W., 1998, Systemy sieciowe battyckiej turystyki przyrodniczej, „Czas Morza”, nr 1(10). 
Turystyka w 1997 r., 1998, GUS, Warszawa.

Ustawa o ochronie gruntów rolnych i leśnych, nr 78, Dz. U., nr 16, 1995.

Prof. dr hab. Aleksander Szwichtenberg

Katedra Turystyki i Zagospodarowania Przestrzennego

Wplynęlo:

Politechnika Koszalińska

ul. Karola Marksa 6E

75-343 Koszalin

\section{RESUME}

L'article a pour but la présentation de quelques solutions permettant d'augmenter les profits économiques résultant de la situation du pays au bord de la mer. On a estimé que la consolidation politique et économique des pays situés au bord de la Baltique, qui constituent la région dite Région Européenne Baltique a sauvé ce bassin méditerranéen et par cela a contribué au développement suivant de l'économie touristique. Cependant ces processus de consolidation, actifs particulièrement dans les annéeas quatre-vingt-dix n'ont pas eu pour effet l'augmentation du mouvement touristique des habitants des pays scandinaves vers la Pologne. On est parti d'un principe que le tourisme dans le pays des lacs doit se développer avant tout à la base de l'idée de l'Anneau Vert de la Baltique embrassant tous les terrains de lacs et forestiers situés autour de la mer.

Il faut accélérer le processus de transformation, celle de propriété privée avant tout pour adapter sans retard la base touristique maritime. Au bord de la Baltique, il manque des hôtels, des motels, des pensions, de la base donc, qui domine dans les pays européens, développant le tourisme maritime. Pour adapter l'aménagement touristique aux valeurs touristiques du milieu naturel dans la zone maritime, il est nécessaire de mettre en pratique le zonage d'impôts, créer l'aire strategique de la commune et procéder à la formation du, ainsi dit, deuxième front d'investissement. Le zonage d'impôts, selon le principe: plus près du littoral, plus haut est l'impôt sur l'immeuble, doit être un instrument principal de la déglomeration des localités maritimes. Bien que les résidences secondaires ne doivent pas être localisées dans la zone maritime, leur construction, en tant que type primordial de l'investissement touristique, doit être réalisée au deuxième front de cette action, c.à d., de 2 à $5 \mathrm{~km}$ de la ligne de côte. Les communes maritimes doivent acquérir succesivement les terres, sur lesquelles, on pourrait investir, pour améliorer les conditions du repos, en traçant les routes périphériques, les objets de commerce et de services, etc.

Traduit par Lucjan Kowalski

\section{SUMMARY}

The aim of the article was to present several ways to increase economic benefits resulting from the fact of being a Baltic country. It has been agreed that the political - economic consolidation of the countries situated on the Baltic Sea, which create the so called European Baltic Region, led to saving this inland reservoir, and, consequently to the further development of the tourist economy. However, these consolidating processes, especially active in the 1990s, did not contribute to the growth of the tourist traffic from the Scandinavian countries to Poland. 
It has been assumed that tourism in Polish seaside regions should be developed mainly on the basis of the idea of the Baltic Green Ring, encompassing all lake and forests areas near the Baltic Sea.

The process of transformation, especially that of the ownership system, should be accelerated, so that the seaside tourist facilities could be adjusted to the European standards as soon as possible. Polish Baltic lacks hotels, motels and guest houses, i.e. the kind of facilities which dominate European countries developing the seaside tourism.

In order to adjust the tourist facilities to the tourist qualities of the natural environment in the seaside region, the tax zoning should be used, a strategic administrative area should be created and so called second investment front should be initiated. Zoning, according to the rule: the closer it is to the coastline, the higher the taxes on real estate are, should be the basic tool in deglomerating the seaside towns and villages. Although "second houses" should not be located in the seaside zone, they should be the main type of tourist investment in the second investment front, i.e. about $2-5 \mathrm{~km}$ from the coastline. The main aim of the seaside administrative units authorities should be gradual purchase of areas where it will be possible to carry out investments improving the conditions of recreation, among other things building ring-roads, shops, service points, recreational objects, etc. 